\title{
COMMUNITY BASED RISK BEHAVIOUR STUDY ON HIV/AIDS TARGETING WOMEN IN NEPAL -2007
}

\author{
Jha K K', Salhotra V S', Weerakoon A P1, Shrestha L', Malla $P^{2}$ \\ ISAARC TB and HIVIAIDS Centre, Kathmandu, Nepal \\ ${ }^{2}$ National TB Centre, Thimi, Bhaktapur, Nepal
}

\section{ABSTRACT}

Nepal has progressed from a HIV low prevalence country to one with a concentrated epidemic in certain subgroups of population. It has been documented that girls and women are more vulnerable to HIV infection. However there is little documented evidence on the risk behaviour among women in Nepal. This study was conducted to assess the pattern of risk behaviour for HIV among women in Nepal.

Methodology : The main component of the study comprised a community based cross- sectional study, using a multi stage random sampling technique. Data was collected by trained field health workers using an interviewer administered questionnaire. Eight focus group discussions were also conducted to supplement the findings. Statistical analysis was carried out using SPSS version 13 .

Results : A significant number of un married (13.7\%) women and $2.2 \%$ of married women indulged in high risk sexual behaviour. A significant positive association was observed between sexual risk behaviour of married women and monthly family income less than 5000 Nepali Rs, age group 25-34y and young age group (15-34) in unmarried women. Nearly $70 \%$ of participatory women have heard about AIDS and have satisfactory level of knowledge about HIVIAIDS. However, significant number of respondents had misconceptions that one could contract HIV through hand shaking, mosquito bites and hugging. Using Condoms during unprotected sexual intercourse in both married and unmarried women were low (19.4\% and $6.2 \%$ respectively). Findings of Focus Group Discussions revealed there is a strong stigma associated with HIVIAIDS in this rural community in Nepal.

Conclusions : One in every seven unmarried woman in Nepal indulged in high risk sexual behaviour, which is much more compared to married women. There is an urgent need for reproductive health education especially among teenagers and for the National HIVIAIDS Control Programme to expand its awareness generation activities.

Keywords : HIVIAIDS, women, risk behaviour, Nepal

\section{INTRODUCTION AND JUSTIFICATION}

It has been documented that girls and women are more vulnerable to HIV infection and its impact. Globally, more

\section{Correspondence to}

Dr V.S.Salhotra

Deputy Director

SAARC TB and HIVIAIDS Centre, Kathmandu, Nepal

E-Mail: salhotrastc@mos:com:np,Vir118@hotmail.com than half of persons living with HIV are females, a sharp contrast to the early stages of the epidemic, when AIDS was thought a disease mainly striking men. Women are vulnerable to HIV infection in many ways. Evidence suggests that large share of new infections is due to gender - based violence in homes, schools, the workplaces, and other social arenas. ${ }^{1}$ Forced or coerced sex renders a woman even more vulnerable to infection; the younger she is more likely it is that she will contract HIV. 
In the Human Development Report 2001, Nepal features among the economically poorest countries in the world. ${ }^{2}$ Nepal's social indicators remain well below the average for the South Asia region: More than 40 percent of the Nepalese population lives below the national poverty line and nearly 60 percent of all adults are unable to read or write. Additionally, women have traditionally a lower status than men and gender inequality is deeply rooted. ${ }^{3}$ Nepal is one of the few countries worldwide in which men live longer than women. More boys than girls receive any form of education, women generally work longer hours than men, and men have better access to services, including health. In Nepal, the topography, environmental degradation, poverty and economic migration are all linked and they combine with other factors to increase vulnerability to HIVIAIDS.

The first HIV infection in Nepal was identified in 1988. Nepal's HIV epidemic is largely concentrated in high-risk groups, especially sex workers (SW) and Injecting Drug Users (IDUs). Injection drug use appears to be extensive in Nepal and to significantly overlap with commercial sex. Another important factor is the high number of sex workers who migrate or are trafficked for work, thereby increasing HIV prevalence in the sex workers' network in Nepal more rapidly. There are many risk factors that put Nepal in danger of experiencing a widespread epidemic. Some of these include cultural, social and economic constraints to condom use, especially with commercial sex workers, and large number of internal and external migrants within Nepal and neighboring countries.

By 2007, the number of People Living with HIVIAIDS (PLHA) in Nepal was estimated at 70,256 persons. As reported to the National Centre for AIDS and STD control (NCASC), Teku, Kathmandu, Nepal and the cumulative number of HIV positive cases including AIDS as of April 2008, was 11234. Among them $68.1 \%$ were males and $31.9 \%$ were females. Out of total HIV positive cases, 1754 were full blown AIDS cases. 232 new cases were added with in April $2008 .{ }^{4}$

Disease is affecting mainly the people in sexually active age group of $15-49$ years. Nearly $92.2 \%$ of the cases are in the age group of $15-49$ years . About $46.6 \%$ of the reported HIV positive cases belong to clients of sex workers followed by Housewives (22.0\%), IDUs (19.0\%) and Sex Workers (7.0 $\%)$. This shows that the number of infected housewives is about three times higher than the number of sex workers. ${ }^{4}$

According to the above epidemiological data Nepal is facing rapid increases in HIV prevalence among high risk groups such as sex workers and injecting drug users. Nepal's poverty, political instability and gender inequity, combined with low levels of education and literacy make the control task more challenging. In addition prevailing denial, stigma and discrimination that surround HIVIAIDS, make this task more difficult. In addition Nepal's HIV epidemic is largely concentrated among high-risk groups, especially female sex workers (FSW) and IDUs, and currently the, problem is increasing among migrants and men having sex with men (MSM). Most of them do not know that they are infected and may be engaging in unsafe sexual practices. ${ }^{5}$ Above demographic and epidemiological findings shows that women in Nepal are vulnerable to HIV infection. Studies on risk behavior on HIVIAIDS targeting women in Nepal are limited. Therefore this study was conducted in Nepal to achieve the following objectives. To identify the risk behavior of Nepalese women in relation to acquiring HIV infection.and to assess the pattern of sexual and other risk behaviour for HIV among women in Nepal.

\section{METHODOLOGY}

\section{Study Design :}

This study consisted of two components

(a) Community based descriptive study

(b) Qualitative component- Focus Group Discussion

\section{Study Setting :}

Nepal comprises of 5 development regions, seventy five districts and 26 Million populations (2004). Geographically, Nepal is dividing into three major areas.

1. Himalayan Area (Mountain )

2. Hilly Area

3. Plain Area (Terai)

Primary stratification was done based on these geographical regions. However, Himalayan area is excluded from the study because of its difficult terrain. Hence, this study was conducted in randomly selected four (4) districts, two from Hilly and two from Terai areas of Nepal, namely Gorkha, Kaski, Parsa and Banke districts.

\section{Study Population :}

The study population comprises females who are residents of these four districts. The following females were excluded from the study:

* Those who refused to give consent for the study.

* Visitors from other areas (Those who are residing in these areas for less than 6 months). 
All women irrespective of their HIV status were included into the study.

\section{Sample Size :}

The sample size in a behavior study depends on the population size and the frequency of the behavior risk condition to be measured. Since there is limited data regarding risk taking behavior for Nepalese, in the present study only the population size was considered when calculating sample size. (10\% of the female population was taken). ${ }^{5}$ Considering above factors a sample of 5423 women permanently residing in study districts was selected.

\section{Data collection procedure :}

In the Wards (village) the first house was randomly selected by the Principal Investigator (STAC staff member) and address was given to relevant Interviewers. Starting from that house interviewer visited each house, which is situated on the right side of the main entrance of that particular house. Like wise required number of females from each village according to the sample size were enrolled and interviewed.

The interviewer visited the houses and enquired whether an eligible woman is residing in the house. If such a woman is present and gave consent, she was enrolled as the first respondent. From there onwards, the interviewer visited the houses as per defined methodology until required numbers of females were enrolled and interviewed. If there were more than one females in a house, all eligible females were selected for the study.

Study Period : 4 months starting from September 2007.

\section{Study Instrument :}

The study instruments were

(1) Interviewer Administered Pre Coded Structured Questionnaire.

(2) Focus Group Discussion : Focus group discussions were employed in each selected district in coordination with district public health office with targeted population involved in different occupations to explore the factors placing them at risk for engaging in HIV risk behaviors and to identify barriers on involving into healthy behaviors.
Formulation of Questionnaire :

Simple and clear colloquial language was used in the formulation of questions. A single variable was measured from each question. Questionnaire consisted of following components

* Demographic data

* Mobility

* Sexual risk behavior

* Risk of injecting drugs

* Knowledge about HIVIAIDS

\section{Pre Testing Of Questionnaire :}

Pre testing of questionnaire was carried out to determine the acceptability, comprehension and ease of administration of the questionnaire. It was pre tested among the adult females in the Kathmandu Valley.

\section{Selection and Training of Field Staff :}

Female Community Health Workers (FCHW) were selected as field investigators to assist the Principal Investigator in data collection. They were selected from the same village. Two days training were given to them prior to data collection by the STAC staff.

\section{Ethical Consideration :}

The following ethical issues were considered in the design of the study.

- The participants were briefed regarding the nature, objectives, and method of the study and their voluntary participation acquired.

- Participants were given free option to withdraw from the study at any point of time.

- The identifiers were not recorded on the questionnaire

- Permission was obtained from relevant authorities before commencement of the study

Analysis of Data :

Statistical analysis was performed by STAC staff using the Computer Programme Statistical Package for Social Science (SPSS) 13 Version. 


\section{Qualitative research component- Focus Group}

Discussions

Eight Focus Group Discussions were completed, two from each districts of target groups. The focus group discussion began with the presentation of a story about a woman with history suggestive of AIDS. The story followed the women throughout the stages of her illness until she became a HIV positive and how her family and the community may respond. This approach allowed participants to speak in the third person about a fictional woman with HIV infection and not feel like the story and their view were reflections of their own thinking.

\section{Participants were then asked:}

$\checkmark$ What is the risk behaviour in that study?

$\checkmark$ Reasons why people are not using condoms?

$\checkmark$ What is the reaction of her (fictional woman) immediate family members and society?

$\checkmark$ How did she (fictional woman) develop the disease?

$\checkmark$ What precautions she (fictional woman) must have taken

$\checkmark$ Stigma related to HIVIAIDS

$\checkmark$ Knowledge about HIVIAIDS

$\checkmark$ Other related issues like avaialability of reproductive services, unwanted pregnancies etc

\section{RESULTS}

A total of 5423 both married and unmarried women were interviewed .Majority of women belonged to 15-24 y age group followed by $25-34$ year age group.Mean age of study population is 27 years. In the study population about 75 percent were married and living with spouse at the time of the survey.Respondents who never married accounted for $20 \%$.Majority $(82 \%)$ of the respondent were Hindu by religion. Nearlry $22 \%$ of study population were illiterate. The distribution of literate study population by completed number of years of education reveals that majority $(59 \%)$ had only primary education. Only 15 women had education up to graduate or post graduate level.Overall, 41 percent of study population was employed at the time of survey. Only $2 \%$ of the respondents reported that they were away from home during the last 12 months for occupation.
Table 1. Socio - Demographic characteristic of study sample

\begin{tabular}{|c|c|c|}
\hline & \multicolumn{2}{|c|}{ Study population (n- 5423) } \\
\hline Age group (in years) & Number & $\%$ \\
\hline $15-24$ & 2574 & $47.5 \%$ \\
\hline $25-34$ & 1716 & $31.6 \%$ \\
\hline $35-44$ & 864 & $15.9 \%$ \\
\hline$>45$ & 269 & $5 \%$ \\
\hline \multicolumn{3}{|c|}{ Mean age -27 years, SD- 8.4 years } \\
\hline \multicolumn{3}{|l|}{ Religion } \\
\hline Hindu & 4448 & $82 \%$ \\
\hline Non-Hindu & 975 & $18 \%$ \\
\hline \multicolumn{3}{|l|}{ Literacy } \\
\hline Literate & 4235 & $78.1 \%$ \\
\hline Illiterate & 1188 & $21.9 \%$ \\
\hline \multicolumn{3}{|l|}{ Educational status } \\
\hline Primary & 3200 & $59.0 \%$ \\
\hline Secondary & 1020 & $18.8 \%$ \\
\hline Graduate & 12 & $0.22 \%$ \\
\hline Post graduate & 3 & $0.06 \%$ \\
\hline Illiterate & 1188 & $21.9 \%$ \\
\hline \multicolumn{3}{|l|}{ Marital status } \\
\hline Never married (Single) & 1088 & $20.1 \%$ \\
\hline $\begin{array}{l}\text { Currently Married(Living } \\
\text { with husband) }\end{array}$ & 4083 & $75.3 \%$ \\
\hline $\begin{array}{l}\text { Currently Married(Not } \\
\text { living with husband }\end{array}$ & 139 & $2.6 \%$ \\
\hline Divorced & 29 & $0.5 \%$ \\
\hline Widowed & 82 & $1.5 \%$ \\
\hline $\begin{array}{l}\text { Living with partner (But } \\
\text { not married) }\end{array}$ & 2 & $0.04 \%$ \\
\hline \multicolumn{3}{|l|}{$\begin{array}{l}\text { Whole family income } \\
\text { (NRs)/month }\end{array}$} \\
\hline$<$ than 2500 & 1469 & $27.1 \%$ \\
\hline $2500-4999$ & 1751 & $32.3 \%$ \\
\hline $5000-9999$ & 1391 & $25.7 \%$ \\
\hline$>$ than 10000 & 812 & $14.9 \%$ \\
\hline \multicolumn{3}{|l|}{ Current occupation } \\
\hline House wife & 3208 & $59.2 \%$ \\
\hline Agriculture & 607 & $11.2 \%$ \\
\hline Student & 846 & $15.6 \%$ \\
\hline Business & 466 & $8.6 \%$ \\
\hline Migrant labour & 26 & $0.5 \%$ \\
\hline Other & 270 & $4.9 \%$ \\
\hline \multicolumn{3}{|l|}{$\begin{array}{l}\text { Last one year away } \\
\text { from home for } \\
\text { occupation }\end{array}$} \\
\hline Yes & 107 & $2 \%$ \\
\hline No & 5316 & $98 \%$ \\
\hline
\end{tabular}




\begin{tabular}{|l|c|c|}
$\begin{array}{l}\text { Husbands educational } \\
\text { status (n-4333) }\end{array}$ & & \\
\hline Primary & 1986 & $45.8 \%$ \\
\hline Secondary & 998 & $23.0 \%$ \\
\hline Graduate & 49 & $1.1 \%$ \\
\hline Post graduate & 38 & $0.9 \%$ \\
\hline Illiterate & 1081 & $24.9 \%$ \\
\hline $\begin{array}{l}\text { Don't know } \\
\text { Husband's migration }\end{array}$ & 181 & $4.2 \%$ \\
for job (last one year ) & & \\
(n-4333) & & \\
\hline Yes & 1625 & $37.5 \%$ \\
No & 2708 & $62.5 \% \%$ \\
\hline
\end{tabular}

The study revels that comparatively more men (24.9\%) were illiterate as compared to women (21.9\%). Nearly $38 \%$ of respondendents reported that their husband were away from home during the last one year for occupation (Table 1).

\section{(C) Sexual risk behaviour (Married women)}

This study revealed that $2.2 \%$ of married women indulge in extramarital sexual act during last one year. Those who had extramarital partners $73 \%$ had a only one partner , $19.4 \%$ had two partners and seven women (7.5\%) stated they had 3 or more than 3 sexual partners (Table 2).

\begin{tabular}{|c|c|c|}
\hline $\begin{array}{l}\text { Sexual partners other than } \\
\text { husband }\end{array}$ & Number & $\%$ \\
\hline Yes & 93 & $2.2 \%$ \\
\hline No & 3990 & $97.8 \%$ \\
\hline \multicolumn{3}{|l|}{ Number of partners $(n-93)$} \\
\hline One & 68 & $73.1 \%$ \\
\hline Two & 18 & $19.4 \%$ \\
\hline Three or more & 7 & $7.5 \%$ \\
\hline \multicolumn{3}{|l|}{$\begin{array}{l}\text { Condom use while having sex } \\
\text { with partner (n-93) }\end{array}$} \\
\hline Yes & 18 & $19.4 \%$ \\
\hline No & 60 & $64.5 \%$ \\
\hline Some times & 15 & $16.1 \%$ \\
\hline \multicolumn{3}{|l|}{$\begin{array}{l}\text { Condom use while having sex } \\
\text { with husband (n-3817) }\end{array}$} \\
\hline Yes & 374 & $9.8 \%$ \\
\hline No & 3015 & $79.0 \%$ \\
\hline Sometimes & 428 & 11.2 \\
\hline
\end{tabular}

This population based survey has also made an attempt to assess the proportion of women who were using condoms while having sex with husband and partners.It was found that nearly $19 \%$ of extra marital partners and $9.8 \%$ of husband's regularly use condoms while having sexual intercourse.

\begin{tabular}{|c|c|c|}
\hline $\begin{array}{l}\text { Reasons for not using } \\
\text { condoms }\end{array}$ & $\begin{array}{l}\text { With husband } \\
(n=3015)\end{array}$ & $\begin{array}{l}\text { With Partner } \\
(n=93)\end{array}$ \\
\hline $\begin{array}{l}\text { Not available at the } \\
\text { time of intercourse }\end{array}$ & $\begin{array}{c}245 \\
(8.1 \%)\end{array}$ & $26(43.3 \%)$ \\
\hline $\begin{array}{l}\text { Not aware about the } \\
\text { importance of the } \\
\text { condom }\end{array}$ & 1769 (58.7\%) & $11(18.3 \%)$ \\
\hline $\begin{array}{l}\text { Husband/partner not } \\
\text { likes to use condoms } \\
\text { due to diminished } \\
\text { sexual sensation }\end{array}$ & $2513(83.3 \%)$ & $46(76.7 \%)$ \\
\hline $\begin{array}{l}\text { Cannot negotiate with } \\
\text { the husband }\end{array}$ & $711(23.6 \%)$ & $36(60.0 \%)$ \\
\hline $\begin{array}{l}\text { Problems of disposing } \\
\text { condoms }\end{array}$ & $26(0.9 \%)$ & $2(3.3 \%)$ \\
\hline $\begin{array}{l}\text { Using other family } \\
\text { planning methods }\end{array}$ & $2678(88.8 \%)$ & - \\
\hline
\end{tabular}

The reasons for not using condoms by husband and partners were assessed. Majority stated that husband/ partner dislike using condoms during sexual intercourse because of diminished sexual sensation. Other common reasons stated were, using other forms of family planning methods, cannot negotiate with the partner and not aware about the importance of the condom (Table 3 ).

\section{(D)Sexual Risk Behaviour of un married women ( $n=1088$ )}

This study revealed that out of 1088 unmarried women $149(13.7 \%)$ of females are indulged in premarital sex (Table 4). Approximetely $24 \%$ of unmarried women who were expeinced sexual activity, had started sexual activity before the age of 15 years (Table 5). It was found that $81.5 \%$ of unmarried women who had a penetrative sex with a partner during last week did not use condoms (Table 5). About $45.5 \%$ of these women have mentioned that they are not aware about the importance of the condoms (Table $6)$. 


\begin{tabular}{|c|c|c|}
\hline $\begin{array}{l}\text { Life time sexual } \\
\text { experience of unmarried } \\
\text { women }\end{array}$ & Number & $\%$ \\
\hline Yes & 149 & $13.7 \%$ \\
\hline No & 939 & $86.3 \%$ \\
\hline Total & 1088 & $100.0 \%$ \\
\hline
\end{tabular}

\begin{tabular}{|c|c|c|}
\hline Age at first intercourse & Number & $\%$ \\
\hline $15 y$ and Less than $15 y$ & 36 & $24.1 \%$ \\
\hline More than 15 years & 113 & $75.9 \%$ \\
\hline \multicolumn{3}{|c|}{ Having current sexual partner } \\
\hline Yes & 48 & $32.2 \%$ \\
\hline No & 101 & $67.8 \%$ \\
\hline \multicolumn{3}{|l|}{ Routes of practising sex } \\
\hline Vaginal & 27 & $93.1 \%$ \\
\hline Oral & 19 & $65.5 \%$ \\
\hline Anal & 6 & $20.7 \%$ \\
\hline Extra Vaginal & 20 & $69.0 \%$ \\
\hline \multicolumn{3}{|c|}{ Condom used during vaginal intercourse ( $\mathrm{n}-27)$} \\
\hline Yes & 2 & $6.2 \%$ \\
\hline No & 22 & $81.5 \%$ \\
\hline Some times & 3 & $11.1 \%$ \\
\hline
\end{tabular}

Table 6:Reasons for not using condoms (Unmarried Women): ( $\mathrm{N}=22$ )

\begin{tabular}{|lcc|}
\hline $\begin{array}{l}\text { Reasons for not using } \\
\text { condoms -Partner }\end{array}$ & No & $\%$ \\
\hline $\begin{array}{l}\text { Not available at the time } \\
\text { of intercourse }\end{array}$ & 14 & $63.6 \%$ \\
\hline $\begin{array}{l}\text { Not aware about the } \\
\text { importance of the condom }\end{array}$ & 10 & $45.5 \%$ \\
\hline $\begin{array}{l}\text { Partner not likes to use } \\
\text { condoms }\end{array}$ & 19 & $86.4 \%$ \\
\hline $\begin{array}{l}\text { Cannot negotiate with the } \\
\text { Partner }\end{array}$ & 5 & $22.7 \%$ \\
\hline
\end{tabular}

\section{(F)Knowledge about HIV/AIDS.}

On an average $70 \%$ of women were aware of HIVIAIDS and condoms.A vast majority of the respondents knew that HIV could be transmitted through unprotected sexual intercourse (84\%) followed by other correct response like infected blood (66\%) and mother to child transmission $(84 \%)$. On the contrary a significant number $(52 \%)$ had the misconception that one could contract HIV through shaking hands with HIV infected person. A further $24 \%$ believed that they might get infected by mosquito bites.

\begin{tabular}{|ll|}
\hline $\begin{array}{l}\text { Table 7: Distribution of respondents by their main } \\
\text { source of information on HIV/AIDS }\end{array}$ \\
\hline Main source of information & Number \\
\hline Television & 3036 \\
\hline Radio & 3126 \\
\hline Newspaper & 1876 \\
\hline Other printed materials & 658 \\
\hline Heath workers & 1356 \\
\hline Parents & 15 \\
\hline Teachers & 47 \\
\hline Friends & 2987 \\
\hline
\end{tabular}

It has been found that television,radio,friends, news paper and health workers were the major source of information for the knowledge about HIVIAIDS (Table 7).

\section{Section G :}

In this study sexual risk behaviour is defined as those women indulging pre marital and extra marital penetrative (vaginal/anal) sexual intercourse.

\begin{tabular}{|c|c|c|c|c|}
\hline & $\begin{array}{l}\text { Sexual } \\
\text { married }\end{array}$ & $\begin{array}{l}\text { sk behavi } \\
\text { vomen }\end{array}$ & & \\
\hline $\begin{array}{l}\text { Age group } \\
\text { (in years) }\end{array}$ & Yes(\%) & No(\%) & Total & $\begin{array}{l}\text { Crude Odds } \\
\text { Ratio \&Cl }\end{array}$ \\
\hline $15-24$ & $\begin{array}{c}23 \\
(1.2 \%)\end{array}$ & $\begin{array}{c}1851 \\
(98.8 \%)\end{array}$ & 1874 & 1(Reference) \\
\hline $25-34$ & $\begin{array}{c}45 \\
(3.3 \%)\end{array}$ & $\begin{array}{c}1301 \\
(96.7 \%)\end{array}$ & 1346 & $2.7(1.6-4.4)$ \\
\hline $35-44$ & $\begin{array}{c}18 \\
(2.3 \%)\end{array}$ & $\begin{array}{c}775 \\
(97.7 \%)\end{array}$ & 793 & $1.9(1.0-3.5)$ \\
\hline$>45$ & $\begin{array}{c}07 \\
(2.8 \%)\end{array}$ & $\begin{array}{c}242 \\
(97.2 \%)\end{array}$ & 249 & $2.3(0.9-5.6)$ \\
\hline \multicolumn{5}{|l|}{ Income } \\
\hline $\begin{array}{l}\text { Less than } \\
\text { NPR } 5000\end{array}$ & $\begin{array}{c}64 \\
(2.6 \%)\end{array}$ & $\begin{array}{c}2376 \\
(97.4 \%)\end{array}$ & 2440 & $\begin{array}{l}\mathrm{OR}=16.7, \mathrm{Cl}= \\
9.9-27.1\end{array}$ \\
\hline $\begin{array}{l}\text { More than } \\
\text { NPR } 5001 \\
\text { (Reference) }\end{array}$ & $\begin{array}{c}29 \\
(1.6 \%)\end{array}$ & $\begin{array}{c}1793 \\
(98.4 \%)\end{array}$ & 1822 & \\
\hline
\end{tabular}




\begin{tabular}{|c|c|c|c|c|}
\hline \multicolumn{5}{|c|}{ Literacy status } \\
\hline Illiterate & 63 & 3183 & 3246 & $\begin{array}{l}\text { OR-0.7,Cl- } \\
0.5-1.1\end{array}$ \\
\hline Literate & 30 & 986 & 1016 & \\
\hline
\end{tabular}

Table 9: Association between sexual risk

behaviour of un-married women and some sociodemographic variables:

Sexual risk behaviour of un-married women

\begin{tabular}{|c|c|c|c|c|}
\hline $\begin{array}{l}\text { Age group } \\
\text { (in years) }\end{array}$ & Yes & No & Total & $\begin{array}{l}\text { Crude Odds } \\
\text { ratio }(\mathrm{Cl})\end{array}$ \\
\hline $15-24$ & $\begin{array}{c}88 \\
(16.4 \%)\end{array}$ & $\begin{array}{c}450 \\
(83.6 \%)\end{array}$ & 538 & $2.2(1.4-3.4)$ \\
\hline 25-34 & 29 & 134 & 163 & $2.4(1.3-3.8)$ \\
\hline
\end{tabular}
$(17.8 \%) \quad(82.2 \%)$

$\begin{array}{ccccc}35-44 & 30 & 338 & 368 & 1 \\ & (8.2 \%) & (91.8 \%) & & \text { (Reference) } \\ >45 & 02 & 17 & 19 & 1.3(0.3-5.8) \\ & (10.5 \%) & (89.5 \%) & & \end{array}$

\begin{tabular}{|c|c|c|c|c|}
\hline \multicolumn{5}{|l|}{ Income } \\
\hline $\begin{array}{l}\text { Less than } \\
\text { NPR } 5000\end{array}$ & 96 & 650 & 746 & $\begin{array}{l}X^{2}=1.4(p> \\
0.05)\end{array}$ \\
\hline $\begin{array}{l}\text { More than } \\
\text { NPR } 5001\end{array}$ & 53 & 289 & 342 & \\
\hline \multicolumn{5}{|c|}{ Literacy status } \\
\hline Illiterate & 127 & 816 & 943 & $\begin{array}{l}X^{2}=0.3(p> \\
0.05)\end{array}$ \\
\hline Literate & 22 & 123 & 145 & \\
\hline
\end{tabular}

Twenty five years to 34 years married women group had a 2.7 times higher risk of indulge in risky sexual behaviour compared to the married women with 15-24 years. This association was statistically significant. There was a significant positive association between younger age group (15-24 and 25-34) and sexual risk behaviour in unmarried women.

There was a significant positive association between low income group and sexual risk behaviour in married women. There is no statistically significant association between income and risk sexual behaviour in un -married women.

There is no statistically significant association between literacy and risk sexual behaviour in both married and unmarried women.

\section{Section H :Findings of Focus Group Discussions:}

Knowledge, Beliefs and Perception about HIV/AIDS
Unmarried participants demonstrated a general basic knowledge of the HIVIAIDS. The knowledge of married women was poor.

Most participants agreed that men are more frequently infected with the disease. The reasons given were that men are more mobile and they are not using condoms while indulging in unsafe sex.

Most married women stated that their husbands are not using condoms during intercourse. Reasons for not using condoms given by participants were

$\checkmark$ Condoms are expensive

$\checkmark$ Not available at the time of intercourse

$\checkmark$ Husbands do not like to use.

Knowledge and practices regarding Intra venous Drugs usage was extremely poor amongst all the participants in the FDGs. This practice is rare in this community.

Majority of participants stated, having sex with migrant persons like truck drivers without using condoms, was the major risk factor by which one can get HIV infection.

\section{Accessibility of education and Health care for women:}

When asked about where most people received their information about HIV/AIDS, health education sessions held by government health staff was mentioned the most. Some participants learned about the disease from Radio and $T V$, neighbours and relatives. Very few mentioned the bill boards as a source of information.

\section{Stigma related to HIV /AIDS:}

When we asked if someone gets (fictional woman) infected with HIV what action they have to taken. Some participants mentioned tendencies of women to hide their disease status because they would not want to upset their family life. These hiding tendencies occur because women fear that if the family (especially husband) and community learn that she has HIV infection then she will be a shamed and ignored or ostracized by the family members and community.

\section{Discussion :}

According to our knowledge this study seems to be the first of its kind in Nepal that attempts to understand sexual risk behaviour and risk perception in relation to HIVIAIDS of women in the country. It begins to address a severe dearth of information, particularly on high-risk sexual behaviour among the women of the country. 
The study has shown that substantial proportions of young unmarried women and nearly $2 \%$ of married women indulge in high risk sexual behaviour.Early sexual experimentation, multiple partners and irregular use of condoms,are common. Knowledge of condoms seems to be superficial and information regarding the risk of unsafe sex and its consequences is inadequate.

Throughout history, societies have dealt with the problem of premarital sex and illegitimacy by strictly supervising young people so that sexual activity does not begin until marriage. ${ }^{6}$ Although premarital sex is socially unacceptable in Nepal, the study has shown that the proportions among sexually experienced unmarried women are quite high.

The findings of the study have some important programme implications. Women are aware of some forms of protection from HIVIAIDS and other reproductive risks in general. However, their information is incomplete and they hold a number of misconceptions. Therefore action is needed to dispel such myths and misconceptions and impart more knowledge of contraception especially condoms.

\section{Socioeconomic Status :}

As expected, a majority (82\%) of the women were Hindu. In this study $20 . \%$ were never married. Less than 3 percent of the respondents reported separation from their spouse. The divorce rate of study population was very low $(0.5 \%)$ .This may be due to socio-cultural practices prevailing in the SAARC region especially Nepal where divorce is unacceptable by the society. This pattern of literacy (78\%) is higher than 2001 census in Nepal, where adult female literacy rate of Nepal was $56.7 \%$. However, the majority of the literate women (59\%) had received only primary education. Majority of women level of monthly income less than 5000NRs (70US\$). Majority of women are house wives (59\%).Others are involved in various occupations such as agriculture, industrial, business, uniformed services, etc

\section{Sexual risk behaviour : married women}

It was found that $2.2 \%$ of the adult married females indulge in extra marital sexual activities. Out of this number (93) $27 \%$ of women stated that they had a sexual relationship with multiple partners which is a high risk for HIVIAIDS.It is alarming that more than $80 \%$ of married women, are not regularly using condoms during intercourse with partners other than husband.

Even though less number of married women reported high risk sexual behaviour in this study, they are at greater risk of getting HIV or other STIs due to transmission from an infected spouse. The results show $37.5 \%$ of married men were currently working in other countries during last 12 months. This fact is consistent with findings of other studies in Nepal. The men subsequently obtain the services of HIV infected Commercial Sex Workers (CSW). ${ }^{7}$ They then return home, transmitting the virus to their unsuspecting wives, who subsequently pass the virus to their unborn children.In a study conducted by Beine in the village of Saano Dumre, Nepal revealed $56 \%$ of the men were reported to be working either in India or further abroad.

\section{Sexual risk behaviour: un- married women.}

Although premarital sex is socially unacceptable in Nepal, this study revealed that out of 1088 unmarried women $149(13.7 \%)$ of females are indulged in premarital sex. It is alarming that $81.5 \%$ of unmarried women who had a penetrative sex with a partner during last week did not use condoms. About $45.5 \%$ of these women have mentioned that they are not aware about the importance of the condoms. This highlights the importance of condom promotion programmes to youths especially school dropouts by National AIDS control programme and other non government organizations working in the field of HIV/ AIDS. Those who indulge in sex, one fourth stated their sexual activity started before the age of 15 years. The first sexual event has clear health implications, since it marks initiation into the sexual act, which is unprotected, and carries a risk of adverse outcome such as unplanned pregnancy and sexually transmitted infection. ${ }^{8}$ Government and non government authorities must address this issue carefully.

A study conducted among young factory workers in Nepal revealed that one in every eight unmarried girls (13\%) had an experience of sexual intercourse prior to the date of survey. ${ }^{9}$ Our study also revealed similar findings $(13.7 \%)$. In a recent study among male and female students in Pokhara, Nepal it was discovered that one third of students were sexually active and that the average age of first sexual experience was between 14 and $17 . .^{10}$ Other studies have also confirmed similar low ages for reported first sexual contact. ${ }^{11}$

\section{Knowledge about HIV/AIDS and use of condoms.}

Knowledge about STDs and HIVIAIDS is often considered to be associated with the behaviour. However, the link between knowledge and behaviour is not automatic; the 
former does not always affect the latter. ${ }^{12}$ For example, a Korean study involving male students and industrial workers found that a large majority of respondents (99\% of students, $96 \%$ of industrial workers) knew that AIDS could be transmitted by sexual intercourse with an infected person. At the same time, more than 9 out of 10 young men in both groups knew about condoms both as a method of contraception and as a means of preventing STIs. However, of those who were sexually active, only $39 \%$ of industrial workers and $48 \%$ of students reported they have used condom in their last sexual intercourse..$^{13}$ Our study findings revealed the similar findings where on an average $70 \%$ of women were aware of HIVIAIDS and condoms.A vast majority of the respondents knew that HIV could be transmitted through unprotected sexual intercourse (84\%) followed by other correct response like infected blood (66\%) and mother to child transmission (84\%).On the contrary a significant number $(52 \%)$ had the misconception that one could contract HIV through shaking hands with HIV infected person. A further $24 \%$ believed that they might get infected by mosquito bites. These findings indicate the need for proper health educational programmes to women by National AIDS control programme. In spite of fair knowledge about HIVIAIDS, only $9.8 \%$ were using condoms during sexual intercourse. The reasons for not using condoms were assessed. Majority stated (83.3\%) that husband/partner dislike using condoms during sexual intercourse because of diminished sexual sensation. Similar finding was reported in the study done by Abdullalla et al (2002). ${ }^{14}$ Other reasons stated were, using other forms of family planning methods and not aware about the importance of the condom. Compared to the married women, the percentage of inconsistent condom users was low among unmarried women (80.6\%).Like married women, most common reasons for not using condom among unmarried women was partner does not like to use condoms. Only $18 \%$ of unmarried women stated that they were not aware about the importance of the condoms. Hence, risk reduction targeted interventions including condom social marketing should be geared for sexually active community members especially for unmarried persons by the National AIDS Control Programme or other organizations. In addition, condom is an effective contraceptive with dual protection and it has hardly any side effects. Of the respondents who received information on HIVIAIDS, the mostly cited sources of information were health workers, Television and Radio. The findings of the present study were compatible with the findings of the study conducted in other countries in the region. ${ }^{15}$
Association between Sexual risk behaviour and other variables:

\section{Age.}

A significant finding in this study was that there was a positive association between young age group and sexual risk behaviour of unmarried women.

The present study was conducted in the main cities of Nepal. Owing to poverty and unemployment in rural areas, migration of young boys and girls aged 19 years and under, especially to main cities located in the region, is very high. According to UNICEF, approximately 200,000 young people (10-19 years) migrate to urban areas in Nepal. In addition, the rapid growth of formal manufacturing sector in Nepal has led to a large influx of young people from rural areas seeking employment in major cities.Many of these young people arrive in the city unaccompanied by parents or other guardians. Owing to poor parental supervision, unmarried women may start sexual experimentation at younger ages and have more exposure to casual relationships.

\section{Monthly household income.}

In married women, monthly household income less than $5000 \mathrm{NRs}$ are significantly associated with indulging risky sexual behaviour. This is an another study heighlighted HIV infection is closely associated with poverty. ${ }^{16}$ Dixit (1996) also concludes that " poverty is the root cause of the problem of AIDS". ${ }^{17}$ Another study of STD/HIV infection among prostitute in Calcutta (based on self reporting) found that extreme poverty, illiteracy and family disturbances were among the factors most responsible for leading them into prostitution. $^{18}$

In the present study, when considering the attitudes towards some aspects of HIVIAIDS at the Focus Group Discussions, the respondents of all 4 areas had unfavourable attitudes towards patients affected with AIDS and other STIs and had discriminating views towards commercial sex workers, girls working in 'Dance Clubs", homo sexual and IV drug users. The respondents were of the view that these groups were solely responsible for the spread of HIVIAIDS. Study done in Sri Lanka in 1992 on a national scale obtained consistent result with the present study with more than $50 \%$ of respondents having discriminatory views towards patients with AIDS. ${ }^{19}$ 
Questioning sexual behaviour in a rural setting in Nepal is a challenge. However one of the goal in HIV / AIDS educational programmes is to promote the use of preventive behaviour. Findings of the present study can effectively be used to prevent HIVIAIDS in Nepal, in future.

\section{Reference :}

1 HIVIAIDS in women (Feminization of HIV Epidemic), STC News letter Vol. XVI, No1, Jan-Jun.2006

2 Human Development Report 2001

3 HIVIAIDS, Vulnerability in South Asia by Dr V Ramamurthy

4 SAARC Tuberculosis and HIVIAIDS Centre; HIV and AIDS in the SAARC Region an update 2008.

5 http://www.unfpa.org/publications /detail.cfm .Behavior surveillance HIVIAIDS- Behavior monitoring; population with higher-risk behaviors 2006

6 World Health Organization -Genewa 1993

7 Smith L (1996). A participatory action research study of health education.KAP regarding sexual information in Nepal. Master's thesis, Health Education, Leeds Metropolitan University.

8 Wellings K, Field J, Johanson A, Wordswoth J. Sexual behaviour and lifestyle in Britain: The national survey of sexual attitudes and lifestyles. Penguin Book Ltc, 27 london, England 1994.

9 Puri Mahesh; Sexual Risk Behaviour and risk perception of unwanted pregnancies and STD among young factory workers in Nepal- 1998. Welcome trust London UK.

10 Schilling K and Parajuli BK.(1996).Knowledge ,attitudes and practices study on HIVIAIDS and sexual behaviour among students in Pokhara Nepal. INF:Pokhara, Nepal
11 Maharjan, Shiba H, Singh M, Peak A, Crofts N.1994.A survey of KAPB in relation to risk of HIV and HIV prevalence among injecting drug users in Kathmandu. Nepal. Lifegiving and Life saving society.

12 World Health Organization -Genewa 1997

13 Rugpao et al, Attitudes towards people with HIV. Social Science Medicine: 1995; 41(4); 557-568

14 Abdullaha ASM, Fielding R, Headley AJ, Ebrahim SH et al , Reasons for not using condoms among the Hong Kong Chinese population: Implication for HIVIAIDS prevention. Sexually Transmitted Infectio 2002; 78: 180-184

15 Pathirana GC, Evaluation of the community impact of an educational intervention on Sexually Transmitted Diseases directed at Primary Health Care workers in the District of Matale. Sri Lanka,(Thesis). Post Graduate Institute of Medicine, University of Colombo, Sri Lanka 2002

16 Poudal M (1994).Poverty, Prostitution and Women. World Helth 47 (6):10-11

17 Dixit S.B(1996). Impact of HIVIAIDS in Nepal. I Red Light Traffic: The Trade in NepaliGirls: ABC Nepal.

18 Chakraborty A.K et al, 1994. Community based survey of STD/HIV infection among commercial sex workers in Calcutta. Journal of communicable disease 26 (3) 161-7

19 Dharmasena MD, Karunarathna LW, Knowledge and Attitude study on HIVIAIDS. Health Education Bureaue, Ministry of Health Sri Lanka. 